\title{
The Ambiguity in Turandot: An Orientalist Perspective
}

\author{
Hong $\mathrm{Yu}^{1}$ \\ ${ }^{1}$ Department of English, Jinling College of Nanjing University, China \\ Correspondence: Hong Yu, Department of English, Jinling College of Nanjing University, Nanjing, Jiangsu, P. R. \\ China. E-mail: hy2958@yeah.net
}

Received: January 28, 2018 Accepted: February 20, 2018 Online Published: February 26, 2018

doi:10.5539/ells.v8n1p114 URL: https://doi.org/10.5539/ells.v8n1p114

\begin{abstract}
The paper analyzes the Orientalization of the characters in Puccini's seminal opera Turandot to prove that the Europeans' perception formation of Asians is a process of "Orientalizing the Orient". Two heroines, Turandot and Liu, suit the two polar extremes of the Asian women stereotypes in the West, dragon lady and Butterfly. Imperious and malicious Turandot and submissive and self-sacrificing Liu are simplified and generalized representations made by Europeans to meet their imaginations. Furthermore, Turandot and Calaf represent the national stereotypes of China and the West respectively. The refugee Prince appears to conquer the uncivilized land controlled by Turandot, a reflection of Western masculine superiority versus Asian feminine inferiority. To reduce the Orientalism associated with the opera, Chinese artists have been endeavoring to authenticate Turandot, yet this Western creation, due to her particular Orientalized characteristics, remains her ambiguity.
\end{abstract}

Keywords: Turandot, Orientalism, stereotypes, authentication

\section{Introduction: Orientalizing China and Chinese}

\subsection{Europeans' Oscillating Perceptions of China and Chinese}

For the Westerners, Chinese were-maybe are-bewildering and sometimes paradoxical. The stereotypes of Chinese ranging from diligent laborers, brilliant Confucian intellectuals, ignorant barbarians and cunning merchants reflect Westerners' oscillating perceptions of China between naive idealization and immutable uncivilization.

Back at the end of the Middle Ages, Marco Polo (1254-1324), an Italian merchant, was the first to fascinate his fellow Europeans about China in The Travels of Marco Polo (2001), which was claimed by some scholars as the backbone of an "orientalist discourse." The book recorded his experience in an affluent and superior China in the sovereignty of Great Khan, and triggered the Europeans' eagerness to explore this treasure of the East. The idealization was enhanced and reinforced during Renaissance (14th-17th centuries) and the early Age of Enlightenment (1620s-1780s) through intellectual encounters. The missionaries and philosophers portrayed China as a high civilization ruled by "philosopher-kings" (Hung, 2003, p. 261). It was worshiped by European intellectuals as "the land of order, morality and diligence" (Honigsheim, 1945, p. 112) and served "as a tool for interpreting the religious customs, the political system, and the social order on [European] continent" (Fucus, 2006, p. 36). In the 20th century, the uncritical admiration proved in the literary works such as Goldsworthy Lowes Dickinson's Letters from John Chinaman and Other Essays (1901), James Hilton's Lost Horizon (1933), etc.

Yet the indefectible image of China had been corroded since the late eighteenth and the nineteenth century when Europe's economic prosperity provoked its economic and political expansion into the rest of the world. A powerful Europe with its uncompetitive commercial and military advantage revealed an utter contempt for a politically, economically and militarily debilitating China. European intelligentsia's attitude changed from Sinophilia to Sinophobia (Jacobsen, 2013). Baron de Montesquieu was among the first to be against China, calling Chinese "the most deceitful people in the world." Rousseau eventually stated that "there is no vice [China] does not master and no crime which it does not know" (qtd. in Demel, 2001, p. 39). The popular phrase "yellow peril," coined by German Emperor Wilhelm II in 1895, stereotyped Chinese and Japanese as a threat and mortal danger, and combined "racist terror of alien cultures, sexual anxieties and the belief that the West will be overpowered and enveloped by the irresistible, dark, occult forces of the East" (Marchetti, 1994, p. 2). 


\subsection{Edward Said's Orientalism}

Europeans' oscillating perceptions have been studied by scholars in a variety of academic fields. Edward Said, when presenting his Orientalism framework, described the Europeans' perception formation a process of "Orientalizing the Orient" in which the West constructs the East from a Western perspective and turns it into the quintessential Other. For example, Kuchuk Hanem, a famous Egyptian dancer, is a typical Oriental woman created by French novelist Falubert as the product of such a process:

...she never spoke of herself, she never represented her emotions, presence, of history. He [Flaubert] spoke for and represented her. He was foreign, comparatively wealthy, male, and these were historical facts of domination that allowed him not only to possess Kuchuk Hanem physically but to speak for her and tell his readers in what way she was "typically Oriental." (p. 6)

The behavior is based upon the hypothesis that in the historical and cultural context, "Occident and Orient is a relationship of power, of domination, of varying degrees of a complex hegemony" (p. 5). In the eye of Europeans, Asians (including Chinese) are "repetitious pseudo-incarnations of some great original (Christ, Europe, the West) they were supposed to have been imitating" (p. 62). The Europeans are inventing Asians when exercising their cultural strength in an attempt to illustrate its "positional superiority."

\subsection{Representations of Orientalism in Plays and Operas}

The perspective would be traced back in Aeschylkus's The Persians, the earliest Athenian play, in which the Persians are crying after they are defeated by the Greeks. The Europeans in the play are strong, invincible, and Asians are fragile and defenseless. Even as China was stilled worshiped and admired, the Europeans' undertaking to domesticate the exotic presented itself in French performance of Voltaire's adaptation of Chinese opera The Orphan of the House of Zhao in the early 18th century. The role of Chinese emperor Genghis Khan entered the stage, "crowned with a cluster of colorful feather and dressed in pieces of cloth and beast fur... [bearing] an iron sword one side on his waist and [holding] in the other hand an impressively mighty bow" (Li, 2009, p. 25), looking more like a wild hunter than the prominent conqueror who built one of the largest empire in history. The costume and the make-up matched French expectation of a Chinese emperor, or Chinese in general.

Susan McClary and Ralph Locke drew upon Said's study of Orientalism when studying 19th century French operas. They read musical and theatrical Orientalism more broadly as "a repository of patriarchal and colonial images of gender, sexuality and ethnicity" and "a regime of power and knowledge" (qtd. in Head, 2003, p. 212). The Oriental images - the Turk, the Japanese, the Chinese - may be accepted as an artistic production, a way named musical exoticism which "exemplified the fictitious nature of art, serving to conjure up an illusion whose authenticity and accuracy were irrelevant" (ibid). The attempt to make Others "intelligible, controlled, and agreeable" validates the statement that the Orient is an alien and it is incorporated "schematically on a theatrical stage whose audience, manager, and actors are for Europe, and only for Europe" (Said, 1979, pp. 71-72). Thus, it fogs the audiences to comprehend the story and characters in an objective approach.

\subsection{Puccini and His Turandot}

Turandot is the product of early 20th century Orientalism. In the West, Turandot has been one of the best-known theatrical Chinese figures. The Western readers met her initially in the "Story of Prince Calaf and the Princess of China" in the French translation of an ancient Persian book, The Book of One Thousand and One Days, by French orientalist François Pétis de la Croix. The Europeans artists soon caught their attentions and "felt compelled to create their own versions of the mythical tale of a marriage-hating Chinese princess" (Melvin \& Cai, 2010, p. 486). When Giacomo Puccini (1858-1924) and his librettists Giuseppe Adami and Renato Simoni started creating the opera in 1920, there had been about 10 operas and three stage plays on Turandot (Bassett, 2012, http://www.peterbassett.com.au/wp-content/uploads/2012/10/The-Many-Faces-of-Turandot.pdf).

Pucci's opera is set in Peking. Princess Turandot is filled with bitter hatred against men because her ancestor, Princess Lou-Ling, was brutally murdered by a prince. To avenge the death, she demands that anyone who wants to wed her should solve three riddles, and those who fail be beheaded. Many suitors thus have lost their lives. Calaf, together with his father, ex-King Timor of Tartary, and their slave-maid Liu, fled to Peking after their kingdom was captured by China. Dazzled by the princess' breathtaking beauty, he determines to take up the challenge as an unnamed prince. He succeeds in giving the correct answers, but the princess is redundant to fulfill her promise. So Calaf offers a deal: he is willing to be killed if she can discover his name by sunrise. On that night, Liu is captured and tortured, but she refuses to reveal Calaf's identity. Before committing suicide, Liu encourages Turandot to find love and utilize the power of love. Touched by Liù's sacrifice and Calaf's devotion, 
Turandot falls in love with Calaf. The opera ends with the happy marriage between Calaf and Turandot.

Working on Turandot was not an easy task due to Puccini's unfamiliarity with China. He yet succeeded in bringing Chinese elements into his opera. First, "Mo-li-hua," a Chinese folk song which was known in Europe was used as its motif; secondly, he utilized gong and xylophone, two Chinese musical instruments. Third, he invented the character of slave-maid Liu, whose obedience contrasted the dominance and coldness of Turandot.

Turandot's premiere in 1926 in Milan was widely hailed as a triumph. And in the following decades, it has been performed on international stages. Despite its musical accomplishments, Turandot has not received positive comments in the academic world. It has been derided by Western scholars as an "unconscious manifestation of racial arrogance" (Metzger, 2003, p. 210). This paper has explored Turandot in the domain of Orientalism, following a typical Orientalist narrative.

\section{Polar extremes of Asian Women Stereotyping}

\subsection{Europeans' Stereotyping of Asians}

In the European colonialism period, Europeans faced the question of how to understand the colonized people who were racially, ethnically and culturally unalike. To simplify the intercultural interaction, Europeans produced over-generalized pictures and images to reflect their patronizing perceptions, to "dominate, disparage, or dehumanize" (Stephan \& Stephan, 2002, p. 130) the colony inhabitants and to rationalize their own invasion and racial discrimination. According to Hooks (1989), "those who dominate are seen as subjects and those who are dominated are seen as objects." The Europeans "have the right to define their own reality, establish their own identities, [and] name their history," and non-European colonized people have their "reality...defined by others, [their] identity created by others, [their] history named only in ways that define [their] relationship to those who are subject" (qtd. in Uchida, 1998, p. 167). The end was the emergency of a group of stereotyped images that catered to the Europeans' idealization or monsterization.

\subsection{Pucci's Butterfly and Dragon Lady}

The European colonization triggered the interest of their writers and artists to delve into foreign elements. For examples, foreign locales are used as settings in Puccini's operas.Said defined the "imaginative geography" as a typical example of Orientalism: "The Orient was almost a European invention, and had been since antiquity a place of romance, exotic beings, haunting memories and landscapes, remarkable experiences (1979, p. 1). Carner \& G. R. (1936) identified three reasons for Puccini's constant indulgence in something exotic: first, Europeans' interest in something foreign compelled the composer; secondly, the exoticism in foreign music inspired the composer to create a new musical style; and third, his fascination in the alien music generated his assimilation of its certain elements and then transformed them into part of his own personal language.

The inhabitants in those foreign lands should also be imaginative. Puccini, in his masterpiece Madame Butterfly (1904), created Madame Butterfly, the Asian women stereotypical model, based on the acknowledged Japanese elements in the West. She is humble, obedient, and loyalty; believes that "she is smaller and less worthy" and her American husband is "tall and strong and is for her the "eye of heaven"" (Corse, 1983, p. 100); and sacrifices her own life for the love of a Westerner. Uchida summarizes the four "rules" such kind of story abides by:

First, the Oriental Woman exists to serve the Western Man, who represents the powerful, the superior, the dominant people. Second, the Oriental Woman chooses the Western Man over Oriental Men.... Third, the Asian woman cannot legitimately become the Western man's wife; the position is saved for the superior, privileged Western white man. Fourth, the child, however, belongs to the white man and his white wife where he child is expected to have a superior life (1998, p. 168).

Madame Butterfly achieves its success principally because it caters to the Occidentals' expectations of ideal femininity - submissiveness, obedience, passivity, and self-sacrificing for a White man, the same characteristics that are possessed by Liu in Turandot. The slave maid calls herself "nothing but a slave" and shares the anguish with the exiled regal family only because Prince Calaf smiled at her once in the palace. Her love to Calaf remains faithful and unconditional, even though he is longing for the passion of another woman. Finally she kills herself to avoid revealing Calaf's true identity. Puccini, in the same way as he did with Madame Butterfly, constructed her as the ideal Asian woman whose nobleness lies in her self-effacement and self-sacrifice and whose silence is the weapon against the bloodthirsty Turandot. His striving exposes the ideological agenda in Orientalism: "the drive to portray, to capture these unfamiliar regions was often motivated, though not always consciously, by Westerners' needs and desires" (Locke, 1991, p. 263).

Turandot, the title role, lies in another end of the spectrum of stereotypical Asian woman. While Liu is diminutive, submissive and faithful, Turandot is fierce, powerful and dominant. She makes her first appearance 
on the balcony of the palace, speechless and emotionless. A decisive, imperious gesture she makes to put the Prince of Persia to death reveals the inhumanity of this character. In the remaining of the opera, Turandot continues presenting herself as a hard-hearted and cruel dragon lady, breaking her promise to marry Calaf though he has solved three riddles, and torturing Calaf's father and slave in an attempt to find Calaf's name. Even her father urges her to withdraw because he does not want to see more deaths. Wilson labeled Turandot as a "machine woman" with "obscure and immovable state of the mind" (2005, p. 437). In contrast to passionate Liu, Turandot hides her emotion; "she merely sings, or hums; she speaks without saying anything, or says too little" (ibid), as her minster comments, "Turandot does not exist." Turandot has such a malicious, vengeful and cold nature that her transformation from an icy emotionless monster to a love-struck woman at the end of the opera comes as an impulsive interruption. Turandot is always remembered as a femme fatale with indifferent and chilling remoteness.

\section{National Stereotypes: West/China and Masculinity/Femininity}

\subsection{China/West}

The paper further states that Turandot and Calaf represent the national stereotypes of China and the West respectively. In the 1920 s as Puccini created Turandot, Europe was enjoying its economic and cultural prosperity and global expansion. China, in the same period of time, suffered the political and economic instability. In the eye of an European, China was associated with barbarism and despotism. At the beginning of the opera, the street of Peking is full of gruesome stakes with skulls of those whom the princess has executed, and the crowd is restless, indecisive and scared of the Princess. It is the image of China in the mind of Puccini and his librettists.

So, a savior is needed to save China. In Turandot, the savior who will bring about the displacements and transformations is Calaf, who represents the West that sets Turandot and her people free from the tyranny of the history. Calaf, the prince in exile, has the goal to "conquer and establish order in the uncivilized land" (Liao, 1990, p. 55) from the very beginning. The moment when he succeeds in solving the riddles, the Chinese crowd prostrates at Calaf's feet and claims him "the King of the world." The Chinese Emperor insists that an oath is sacred and his daughter should wed the Prince. Turandot is desperately against on the other people. Her shouting that "No one will ever possess me!" is like the yelling of a shrew. Calaf, in contrast, is brave and confident, even patronizing. "[W]hile the mysteries of the Princess of China can be decoded, even though with difficulty, the identity of the alien Prince remains unknown, until he reveals it himself" (p. 56). Tragically, he is the conqueror waiting for the surrender.

Liu, the slave-maid, is the catalyst accelerating the supremacy of Calaf. Some critics see the story as a struggle before Turandot and Liu. It is Liu who successfully humanizes Turandot to be a warm, emotional woman. As Liao stated,

...the "foreigner" Liu, through revealing the magic of love, gives herself the power to face torture and death while simultaneously releasing Turandot from the evil spell of Princess Lou Ling, an ancient Chinese princess who had been tragically betrayed by a foreign conqueror "thousands and thousands of years ago." It is as if the Chinese cannot free themselves from their evil past but must seek a solution from outside-in this case, first Liu and then Calaf. (p. 51)

\subsection{A Parallel between West/China and Masculinity/Femininity}

A further exploration of the relationship between Calaf and Turandot can see a parallel between West /China and masculinity/femininity. Sharp, when studying the convergence of gender identity and nation-state identity, stated that men are "incorporated into the nation metonymically" and women are "mothers of the nation or vulnerable citizens to be protected." It is the metonymic bond of male citizens who must act to save or promote the female nation (1996, p. 99). Said defined the relationship between the West and East as "a relationship of power, of domination, of varying degrees of a complex hegemony" (1979, p. 5), which can be metaphorically alluded in terms of, the relationship between man and woman. The Orient with devious cultural practices must be discovered and dominated, just as deviant and inferior women must be dominated and defined by men. Calaf's triumph implies the typical orientalist contrast between Western masculine superiority versus Asian feminine inferiority.

\section{Authenticating the Chineseness of Turandot}

The Western creation of a blood-thirsty Chinese princess has been unaccepted by Chinese for a long time. Wei Minglun, the famous Chinese playwright, accused Puccini's opera of being "a fairy tale that the occidentals have fabricated... without an understanding of Chinese culture" (qtd. in He, 2012, p. 552). In his revised version, the Prince grieves the death of Liu and rejects Turandot's love. Turandot, however, insists on renaming herself Liu 
and follows him to lead a reclusive life. The revision challenges the distorted images in Puccini's opera. The Chinese philosophy, including harmony, Confucian propriety and ethical standard, determines both the hero and heroine to make Chinese choices.

In spite of the contemporary artists' attempts to enrich the Chinese elements on the stage, the productions of Turandot still follow the Western-centered, objective interpretative tradition toward the East to fulfill the cross-cultural fantasy. There are many ways to doubt Turandot's Chineseness. First, the name Turandot means the daughter in Turan, a region in central Asia controlled by Mongol Empire. She does not sound like a Chinese, at least not a Han princess. Second, feudal Chinese society was controlled by the masculine value system, and "a woman's identity was defined in terms of her unquestioning obedience and deference to the authority of her husband's household at marriage and her eternal attachment to it" (Leung, 2003, p. 361). Confucian ethics accepted the subservience of women to men as natural. Even a woman in a higher status should follow these rules. "No Chinese princess would ever behave as coldly and cruelly as Turandot...Neither would she be so unfilial as to refuse to marry." (Melvin \& Cai, 2010, p. 488). Turandot's identity thus, is ambiguous.

\section{Conclusion}

Oriental fantasies have been inspiring the artistic creativity in European music, paintings and literature. Turandot represents a perfect union of the Oriental exoticism and the occidental love-suiting theme. The Chinese princess has traveled in Persia, France, Italy, Germany and China for more than two hundred years. Yet the questions about her characteristics and cultural identity have been explored by the scholars worldwide.

Puccini's Turandot is simple. It is made up of a bloodthirsty princess who has the aim to revenge against men in the world but gives herself over completely to the love of a man at last; of an exiled prince who attracts the princess for nothing but her beauty and wins her body and soul at last. But does the Chinese princess in a patriarchal society have too much power to determine her own fate and kill any men? The contradictory messages found oblivious manifestations without universally accepted explanations. Facing the danger of "Western discourse on the Orient," (Said, 1979, p. 223), Chinese playwrights and artists continued revising "the original plot and characterization to resist the "Orientalism" of the original play (He, 2012, p. 552). The ambiguous image of Turandot will appear on different stages and the studies on this Western creation of theatrical Chinese figure can take more multifaceted and multicultural approaches.

\section{References}

Bassett, P. (2012). The many faces of Turandot. Retrieved from http://www.peterbassett.com.au/wp-content/uploads/2012/10/The-Many-Faces-of-Turandot.pdf

Carner, M., \& G. R. (1936). The exotic element in Puccini. The Musical Quarterly, 22, 45-67. https://doi.org/10.1093/mq/XXII.1.45

Corse, S. (1983). Mi chiamano Mimi: The role of women in Puccini's opera. The Opera Quarterly, 1, 93-106. https://doi.org/10.1093/oq/1.1.93

Demel, W. (2001). The images of the Japanese and the Chinese in early modern Europe: Physical characteristics, customs and skills. A Comparison of different approaches to the cultures of the Far East. Itinerario, 25(3-4), 34-53. https://doi.org/10.1017/S0165115300014972

Fuchs, T. (2006). The European China-receptions from Leibniz to Kant. (Martin Schonfeld Trans.). Journal of Chinese Philosophy, 33, 35-49. https://doi.org/10.1111/j.1540-6253.2006.00334.x

He, C. (2012). The ambiguities of Chineseness and the dispute over the "homecoming" of Turandot. Comparative Literature Studies, 49, 547-564. https://doi.org/10.1353/cls.2012.0056

Head, M. (2003). Musicology on Safari: Orientalism and the spectre of postcolonial theory. Music Analysis, 22, 211-230. https://doi.org/10.1111/j.0262-5245.2003.00180.x

Hoigsheim, P. (1945). Voltaire as anthropologist. American Anthropologist, 47, 104-118. https://doi.org/10.1525/aa.1945.47.1.02a00060w

Hung, H. (2003). Orientalist knowledge and social theories: China and the European conceptions of East-West differences from 1600 to 1900. Sociological Theory, 21, 254-280. https://doi.org/10.1111/1467-9558.00188

Jacobsen, S. G. (2013). Chinese Influences or Images? Fluctuating histories of how enlightenment Europe read China. Journal of World History, 24, 623-660. https://doi.org/10.1353/jwh.2013.0076 
Leung, A. S. M. (2003). Feminism in transition: Chinese culture, ideology and the development of the women's movement in China. Asia Pacific Journal of Management, 20, 359-374. https://doi.org/10.1023/A:1024049516797

Li, Cheng (2009). Imaging the Chinese on early American stage and screen. Shanghai: Shanghai Jiao Tong University.

Liao, P. (1990). "Of writing words for music which is already made": "Madame Butterfly, Turandot" and Orientalism. Cultural Critique, 16, 31-59. https://doi.org/10.2307/1354344

Locke, R. P. (1991). Constructing the oriental “other": Saint-Saens's Samson et Dalila. Cambridge Opera Journal, 3, 261-302. https://doi.org/10.1017/S0954586700003530

Marchetti, G. (1994). Romance and the "yellow peril": Race, sex and discursive strategies in Hollywood fiction. Berkley, London: University of California Press.

Melvin, S., \& Cai, J. (2010). Turandot in China: rejected, reinterpreted, reclaimed. The Opera Quarterly, 26, 486-492. https://doi.org/10.1093/oq/kbq029

Metzger, S. (2003). Ice queens, rice queens, and intercultural investment in Zhang Yimou's Turandot. Asian Theatre Journal, 20, 209-217. https://doi.org/10.1353/atj.2003.0024

Said, E. (1979). Orientalism. New York: Vintage Books.

Sharp, J. R. (1996). Gendering nationhood. In Nancy Duncan (Ed.), BodySpace: Destabilizing geographies of gender and sexuality (pp. 97-107). London, New York: Routledge.

Stephen, C. W., \& Stephan, W. G. (2001). Cognition and affect in cross-cultural relations. In William B. Gudykunst \& Bella Mody (Eds.), Handbook of International and Intercultural Communication (2nd ed., pp. 127-142). Thousand Oaks, CA: Sage Publications.

Uchida, A. (1998). The Orientalization of Asian women in America. Women's Studies International Forum, 21, 161-174. https://doi.org/10.1016/S0277-5395(98)00004-1

Wilson, A. (2005). Modernism and the machine woman in Puccini's "Turandot". Music \& Letters, 86, 432-451. https://doi.org/10.1093/ml/gci1

\section{Copyrights}

Copyright for this article is retained by the author(s), with first publication rights granted to the journal.

This is an open-access article distributed under the terms and conditions of the Creative Commons Attribution license (http://creativecommons.org/licenses/by/4.0/). 